\title{
AMA: Hill heavyweight or bull in a china shop?
}

When it comes to lobbying to get more government money funneled toward physicians, the American Medical (AMA) Association is the proverbial 800pound gorilla that sits wherever it wants. And some people say the AMA occasionally sits on its friends and benefactors.

The nation's biggest physician group is the best-organized, best-funded healthcare lobby in the US capital. The AMA's organization and clout makes it one of the more formidable opponents one can face on Capitol Hill - and one of the best allies.

But other lobbyists for physician and hospital groups, along with some congressional insiders, say the AMA's lobby sometimes uses its organization and clout clumsily, damaging its relationships with potential allies and the real power brokers on Capitol Hill. "They have played a sort of 'only-game-intown,' swaggering role that has not always been pleasing to the entire profession," said one medical specialty group official, who asked not to be identified.

The same official pointed to the decline in membership as a sign that physicians have wearied of the AMA's clumsy use of its power both inside and outside Washington. Although it has 290,000 members, the AMA has seen its membership shrink to slightly more than forty percent of all US physicians. Furthermore, it is attracting less than one-tenth of the physicians that become eligible for membership each year.

A telling illustration of the AMA's use, or abuse, of its lobbying muscle can be seen during Congress' fierce debate on Medicare reform in October 1995. At that time, House Speaker Newt Gingrich (Republican, Georgia) wanted to meet in his Capitol hill office with top AMA officials, hoping to seal a deal under which the AMA would support the Republican leadership's Medicare reform plan by purchasing advertisements and mobilizing its politically powerful physician advocacy network. Although the AMA had initially backed reform efforts, its support wavered when it became clear how much of the planned US $\$ 270$ billion in savings would come from Medicare physician payments.

In announcing an agreement with the Republicans that ultimately earned the
AMA's support, AMA officials told reporters that the deal averted billions of dollars in Medicare physician fee cuts.

That disclosure - described as a "bonehead maneuver" by one Capitol Hill insider who attended the deal-making meeting - gave Democrats an opening through which to publicly attack the deal as a "bribe" aimed at getting the support of organized medicine.

As a result, the Republican leadership and the AMA not only spent the following day publicly denying a quid pro quo, it also significantly chilled the relationship between the two groups. Some congressional staff members wouldn't even talk to AMA lobbyists, according to sources close to the negotiations.

Other sources familiar with the incident said the AMA's relationship with House Republicans still has not recovered from what the latter consider a mischaracterization of the meeting.

"There's a degree of frustration when people, for whatever purpose, misrepresent what goes on at a meeting," said Rep. William Thomas (Republican, California) who, as chairman of the House Ways and Means Committee's health subcommittee, attended the meeting. "That was a bizarre situation," he said.

An AMA official, however, denies the incident had any effect. "I think we have a good relationship with the lead. ership," said Richard Deem, AMA's vice president for federal affairs and coalitions. According to Deem, the AMA lobbyists are "aggressive, forceful advocates. We do not step out of bounds. If we did, we would no longer be as effective."

Lobbyists for other providers say the AMA's power can complicate formation of the provider-group coalitions that frequently form around issues. These lobbyists, who also spoke on condition of anonymity because they don't want to jeopardize future alliances with the AMA, say the AMA frequently will not compromise for the greater good of the coalition. and splits off when circumstances force the coalition to tack even slightly away from AMA's course.

"I don't have any contact with them the same way I don't have any contact with the Flat Earth Society," said one healthcare lobbyist who views the AMA as backward-looking in its view of the healthcare marketplace. "We just don't want them against us. Put them on the sidelines. If they're there, I'm happy."

The issue of the role of the AMA in directing federal health policy has arisen again recently, as hospital groups have begun pitching members of Congress on the idea of federal licensure of provider-sponsored organizations, or PSOs, so that they can contract directly with Medicare. Although both the AMA and the coalition of hospital groups led by the American Hospital Association (AHA) want to give greater freedom to provider-led networks to contract directly with Medicare, the AMA has not come out in support of AHA language, which has been introduced this year in the Senate by Senator William Frist (Republican, Tennessee), a heart and lung transplant surgeon.

Some healthcare lobbyists said that they suspect the physician group would like the federal government to permit the networks to provide a greater portion of services through contract providers than the AHA-led group wants. The hospital lobbyist said he believes the AMA will seek to weaken the language in the AHA-supported PSO bill that requires a substantial portion of services to be delivered by network providers. "We'll probably end up together," the healthcare lobbyist said.

Indeed,Deem said AMA is "working with" both Frist and AHA. "What's the big picture? We support PSOs," Deem said.
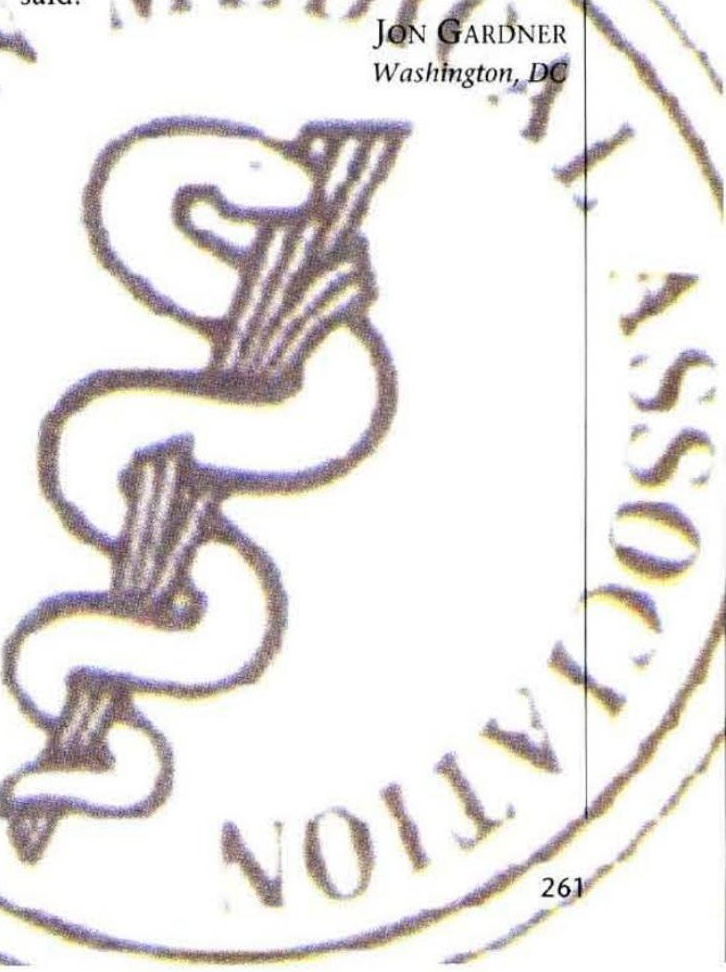